\title{
CUBA SURFACE ESTIMATION FROM SHORELINE MAPPING, GENERATED BY SENTINEL-2 IMAGE PROCESSING
}

\author{
Dayamit Ojeda Martínez*, Pedro Martinez Fernández, Pavel Cesar Matamoros Fombellida, \\ Meylin Morejón González, Ricardo Álvarez Portal, Kenia Labori de la Rosa \\ GEOCUBA Reserch and Consultancy, Loma y 39, Plaza de la Revolución Municipality, La Habana Province, Cuba - (dayamit, \\ pedro, pavel, meylin, richar, kenia)@uct.geocuba.cu
}

\section{Commission III}

KEY WORDS: cartography, surface estimation, shoreline, image processing, Sentinel-2.

\begin{abstract}
:
The coastal with its geographical elements are modified over time, changes that may occur in the long or short term so, shoreline represented in the cartographic documents does not always match with reality. Also, the coastline does not have a well-defined length as results from the fractal-like properties of coastlines, i.e., the fact that a coastline typically has a fractal dimension so, its representation depends to many factors like the cartographic method used, the resolution of the image and the scale of the map. On the other hand, the shoreline is general use to estimate the surface of the landmass, so is important to get a cartographic product with accuracy in a time. Taking into account these elements, this paper is focus in a surface estimation of total Cuban island and keys. To achieved, an expeditious method was used, from the application of geometric corrections to multispectral SENTINEL-2 images, followed by a band algebra using the NDWI index. After those process the automated extraction of shoreline was conducted and finally, refining the vectors by cartographic editing without compromising the accuracy of the results. As a result, two coast lines were obtained from the territory, one in the rainy season and the other in the dry season. The spatial analyses were oriented to surface determination and they were carried out over shoreline in dry season and rainy season, the results were contrasted with the official data published in 2016.
\end{abstract}

\section{INTRODUCTION}

\subsection{Overview and related work}

According to the Spanish Academy of Language (2017), surface is understood as a magnitude that expresses the extension of a body in two dimensions, length and width, and whose unit in the international system is the square meter. Nevertheless, from the geo-space point of view, the Earth is graphically represented by the topographical maps, therefore; The step of the surface of the earth to its representation on a plane surface, consists of projecting the same on one terrestrial ellipsoid, issue relative to Geodesy, and afterwards projecting terrestrial ellipsoid on the blueprint, issue relative to the cartographic projections (Salitchev, 1979). In the last century the cartographer's fundamental training consisted in representing, on the paper, the terrestrial surface in a specific projection. Today, the contributions of information technology offer the ability of representing any area with coordinates known in any cartographic projection (Kraak \& Ormeling, 2010). Therefore, the determination of the terrestrial surface depends on the above-mentioned aspects and techniques that are used for its representation in an either digital map or in a paper format.

The estimation of the surface of Cuba dates back from the 19th century. Successively, the amount of square kilometers of the country has kept on varying. The explanation of such variations is based fundamentally on the fact that as the methods and the technologies of the making of maps, as well as the geodesic measurements have been improved to perfection, the exactness of the works themselves has also been raised in this sense. To what it is added the changes of the territory due either to anthropoid activity, the morphogenesis or to the influence of the meteorological and climatic phenomena. Nevertheless, if the information published by the (Instituto Cubano de Hidrografía, 1989) and by (ONEI, 2016) is verified, they coincide in which the Cuban archipelago comprises the Island of Cuba with five other sub-archipelagos adjacent to its coasts. The Island presents a coastal extension of $5746 \mathrm{~km}$ and the Isle of Youth has $327 \mathrm{Km}$ of coast span, just as the Cuban Archipelago has a surface of $109884,01 \mathrm{~km}^{2}$, which is why it is assumed that the last estimate was made based on cartographic tools of the 1980`s.

One of the key elements for the calculation and appraisal of the surface of Cuba, since it is a land surrounded by the sea, is the coastline that has also been modified in the course of time. The trajectory represented in the cartographic documents not always match with the reality due to the mentioned changes, which is why a new line applying an expedite procedure without compromising the accuracy of the results was needed and that the whole island and keys of Cuba were updated as a main goal.

Existing shoreline mapping techniques vary from simple measurements made directly from uncorrected aerial photographs to precise measurements made from computer rectified aerial orthophotographs in digital format (Moore, 2000). In addition to this, numerous Earth observation satellites nowadays provide almost continuous monitoring of many of the world's coasts.

The more common technique applied in Cuba for detection of shoreline is the visual interpretation, either in the field, by aerial photography or satellite images, where the methods proposed by (Martínez Serrano, 2010) and (Curra Sánchez, 2012) stand out with significant results but with the disadvantage of doing the vector in a manual way which takes a long time, which is a problem if a national scope is needed, and also the operator's specialization is essential. Other ones like (Álvarez Portal, 
Interián Pérez, Ojeda Martínez, \& Mantilla Áviles, 2009), (Olivera Acosta, 2015), have also worked, in the semiautomatic extraction of the coast, using the infrared available band in satellite images, also with good results but with the disadvantage of doing the vector over the pixel shape of the image. That process requires next a smoothing process in addition to the traditional processes of cartographic edition.

Experiences like the ones of (Hapke, Himmelstoss, Kratzmann, List, \& Thieler, 2010), (Maglione, Parente, \& Vallario, 2014), (Y. J. Choung, 2015) and (Y.-J. Choung \& Jo, 2017) and the National Oceanic and Atmospheric Administration (NOAA) based the extraction of the coast on the normalized differential water index: NDWI, since they can extract the information more conveniently than any other classification methods. This index maximizing the properties of reflectance of water using green lengths of wave and minimize the low reflectance in the infrared one as well as maximizing the high reflectance of the infrared due to the terrestrial vegetation and the characteristics of the ground, which makes it suitable for delimitation landwater (Emran, Rob, Kabir, \& Islam, 2016), and it can calculated by the equation number 1 :

$$
N D W I=(\text { green }-I R) /(\text { green }+I R)
$$

From the previous elements, a method for the extraction of the shoreline was formulated. Subsequently, using the new shoreline the surface estimates were carried out as the objective of this investigation.

\section{METHODOLOGY}

\subsection{Summary of methodology process}

It was used as a primary data for the extraction of the coast line the information of remote sensing provided by SENTINEL 2 program and referred to 2016 year. This program was created with the objective of providing high-resolution multispectral images for studies of vegetation, soil and water coverage, internal navigation routes and coastal areas. Each SENTINEL-2 image is made up of 13 bands or regions of the electromagnetic spectrum.

In this work, the visible spectrum bands (Red, Green and Blue) with a spatial resolution of 10 meters were used, as well as a near infrared band. Furthermore, the images of program Rapid Eye were used during the processes of georeferenced. During the checking of the final result we also used image referent to the Google Earth app, and ortophotographies provided by aero cartographic surveys of the coast with Unmanned Aerial Vehicle (UAV). In addition, during the process of checking the results, the GNSS receiver was used. It is composed for ublox ${ }^{\circledR}$ NEO-M8N, attached to a Tablet, compatible with WAAS/EGNOS/MSAS with precision positioning $2 \mathrm{~m}$ outdoors.

The method used in this work consisted in the following order of processes: (1) primary data acquisition, (2) images selection and mosaics building (3) images pre-processing, (4) NDWI calculation and extraction of the land-waters boundaries, (5) cartographic edition, (6) check-up the results, and (7) surface estimation.

\subsection{Acquisition of the primary data}

Initially, the work focused on identifying the coverage of images SENTINEL 2 corresponding to the zone of the Cuban archipelago, for which the worldwide program grid was downloaded in shp format, it was cut out in such a way that it covered the national territory and bordering seas as shown in Figure 1, so as to later on identify the images that covered territory as shown in the Figure 2.

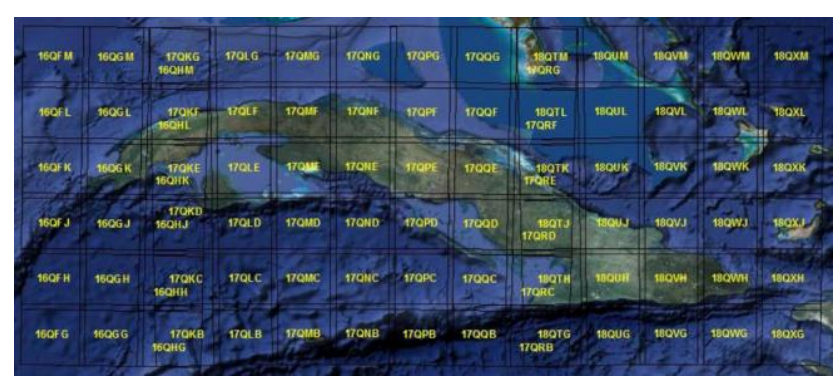

Figure 1. Grid of the SENTINEL 2 corresponding to Cuba and surrounding seas.

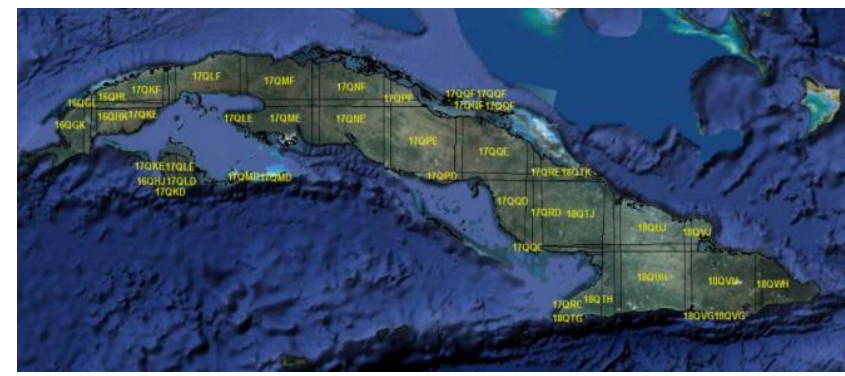

Figure 2. Grid of the SENTINEL 2 for Cuba.

It was concluded that there is a total of 32 images that guarantee a total coverage of Cuba, Isle of Youth and keys. Focused in this study, it was decided to accomplish it the downloading of the images in two stages of the year that would cover both the drought and rainy seasons in order that the same ones had a relatively similar behavior as to conditions of humidity and incidences of the solar radiation, specifically in the periods of January-February-March and July-August-September respectively.

\subsection{Images selection and mosaics building}

The best images corresponding to the same road, row and time of the year were reviewed and selected to make cloud-free mosaics.

\subsection{Images pre-processing}

SENTINEL 2 images are L1C products, made up of orthoimages in UTM / WGS84 projection, and it results from using a Digital Elevation Model (DEM) to project the image cartographically. The radiometric measurements per pixel are provided in reflectance of the top of the atmosphere (TOA) along with the parameters to turn them into radiances. L1C Products are resampled with a constant land sampling distance (GSD) of 10, 20 and $60 \mathrm{~m}$ depending of the native resolution of the different spectral bands (European Space Agency, 2017).

In short, images have a level of geometric and radiometric correction. Nevertheless, they can be out of position even in sequences of images of the same scene. Therefore, the first step 
that should be done is the checking of the geometric coincidence and the georeference by very high-resolution image or terrain reality. In this case the coordinates of RapidEye program were used, which has $5 \mathrm{~m}$ of space resolution, there is a coverage of the whole island of Cuba and no position shifts have been detected in previous verifications.

\subsection{NDWI calculation and extraction of the land-waters boundaries}

This process was carried out in the QGIS software where the corrected image in the previous steps was added and the equation (2) was applied to get the image in NDWI by using Raster Calculator tool. The NDWI resulting image is made of pixels with values between 1 and -1 , where the 0 value is considered to be in the water and land frontier. This value was vectorized automatically by an interpolation process.

\subsection{Cartographic edition}

As the coast is faithfully represented, other elements are also obtained within the land-water border, such as the coastal lagoons, the areas of rice planted by dikes, the salt flats, the reservoirs, the rivers and the pools in residential coastal areas. Therefore, the process of edition presupposes (1) elimination of every object that does not represent the coast element, (2) check out of the coast according to the infrared image of SENTINEL, also can be use RapidEye images, Google or another one available of better space resolution, (3) manual vectorization of missing or defective sectors due to the presence of clouds, (4) union of the sectors of coast with their consecutive ones to achieve the whole national territory and checking of the unions from the use of Topologic tools, (5) creation of the metadata and saving of the information in interoperable format.

\subsection{Check-up the results}

It can be considered that one of the key moments within the methodology is constituted by the process of verification of the data obtained in the digital processing of the images, the automated extraction and the posterior cartographic edition. The procedures that were used are based on the methods of observation such as: (1) field work with the image, the generated line and the GNSS radio receiver described in this material. Considering that the SENTINEL-2 images has a space resolution of $10 \mathrm{~m}$, and our GNSS radio receivers offer precision between 3 and 5 meters, it can be used; (2) in the case of the sectors that were not verified in the field, rectified orthophotographies were used with space resolution of $6 \mathrm{~cm}$, and fitting well into the National Geodesic Network.

In either of the applied variants (1) or (2), the calculation of the root mean square error was made as well as the planimetric accuracy of the shoreline, taking as true terrain the points measured in the field or determined in the very high resolution orthophotographies. The root mean square (r.m.s) and the planimétric accuracy are calculated by means of the following equations.

$$
\begin{aligned}
& \text { r.m.s } \quad \sigma x=\sqrt{\frac{\sum_{n}^{1} \Delta X^{2}}{n-1}} \quad \sigma y=\sqrt{\frac{\sum_{n}^{1} \Delta Y^{2}}{n-1}} \\
& \text { planimetric accuracy } \quad \sigma x, y=\sqrt{\left(\sigma x^{2}+\sigma y^{2}\right)}
\end{aligned}
$$

\subsection{Results and Discussions}

For the surface assessment, the data bases referred to Lambert's Conical Conformed projection were previously built, on the ellipsoid Clarke 1866, the Datum NAD27 updated with the parameters of the GPS National Campaign and the parameters of North Cuba. The coast vectors generated in both rainy and drought seasons were incorporated to the data base. The linear vectors were turned into polygons themselves and from them the calculations of the whole area of the Cuban Archipelago were made (Island of Cuba, Isle of Youth, and the keys), the total extension of coast was estimated too per every season of the year, as well as the number of emerged elements (keys, isles and smaller keys). For this last case, we discriminated all those elements that have generated in the automated process within an area smaller than $80 \mathrm{~m}^{2}$, considering that $10 \mathrm{~m}$ images of space resolution were used and assuming that above this area the presence of noises is considered.

A total of 219 SENTINEL-2 images were downloaded, 112 of them corresponding to the first quarter of the year 2016 and 107 corresponding to the third quarter of the same year. Figure 3 shows part of the developed process. The figure represents a sector of the Southern coast with several SENTINEL 2 scenes previously transformed to NDWI over the Google Earth view. Figure 4 represent a zoom in contained in red square as part of the vector resulted and edition of the coast vector.

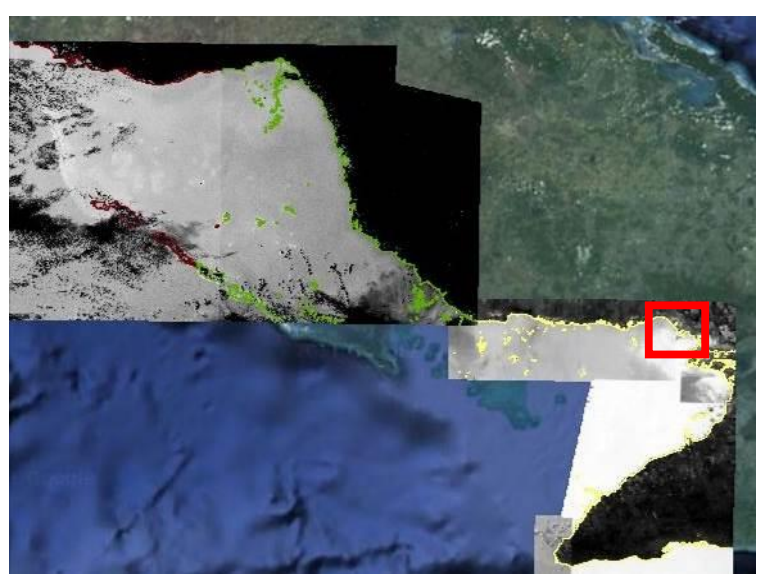

Figure 3. SENTINEL-2 images transformed to NDWI over Google Earth.

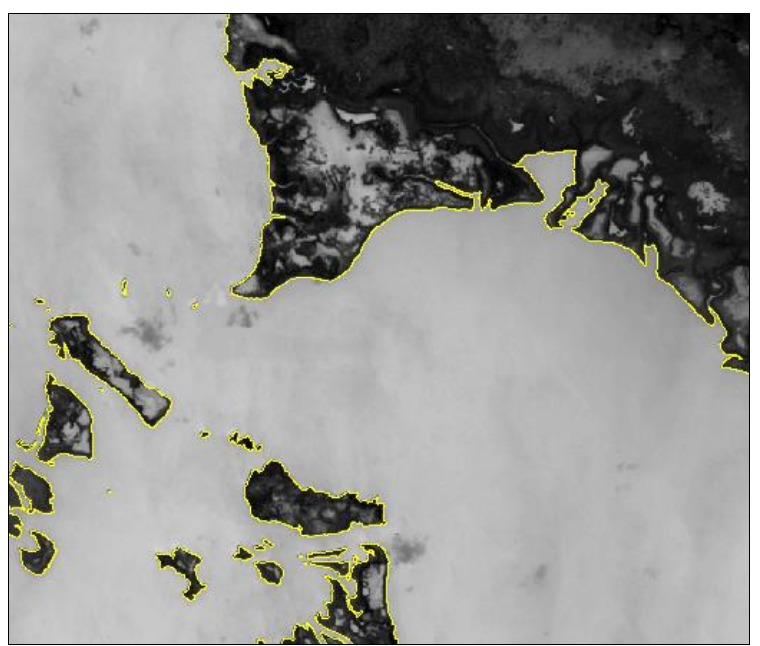

Figure 4. Zoom in to vector create over SENTINEL-2 images transformed to NDWI. 
Figures from 5 to 9 represent the results of the process of vectorization upon the previously transformed SENTINEL 2 images and checked in different kinds of coasts from the vector overlap over high-resolution images related to different place.

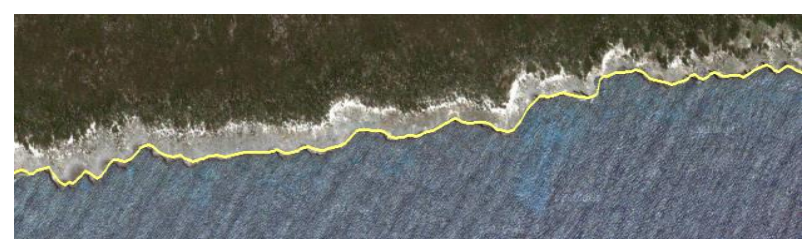

Figure 5. Result of the vector generated over an abrasive coast sector.

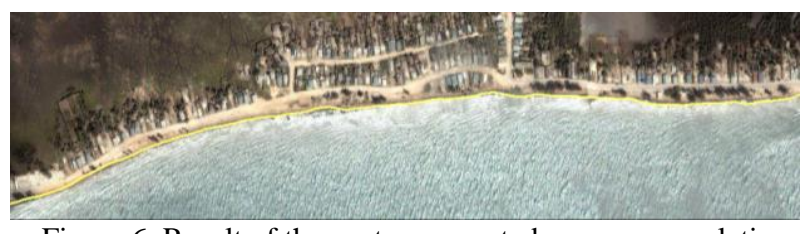

Figure 6. Result of the vector generated over an cumulative coastal sector.

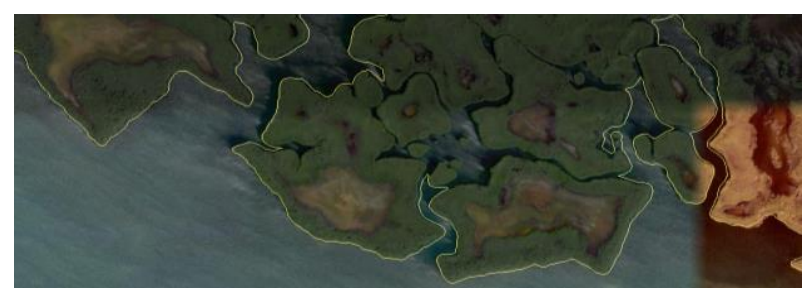

Figure 7. Result of the vector generated over a vegetation coastal sector.

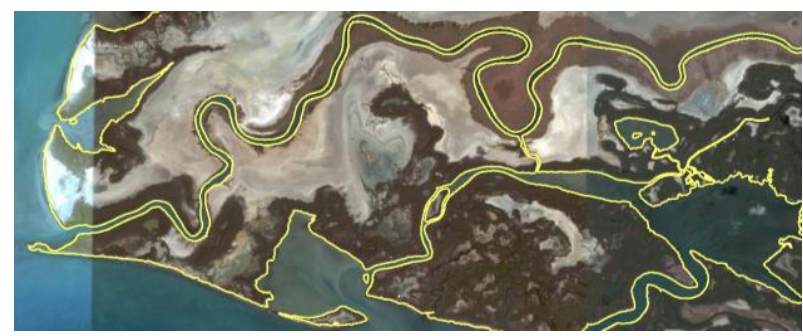

Figure 8 . Result of the vector generated over a marsh coastal

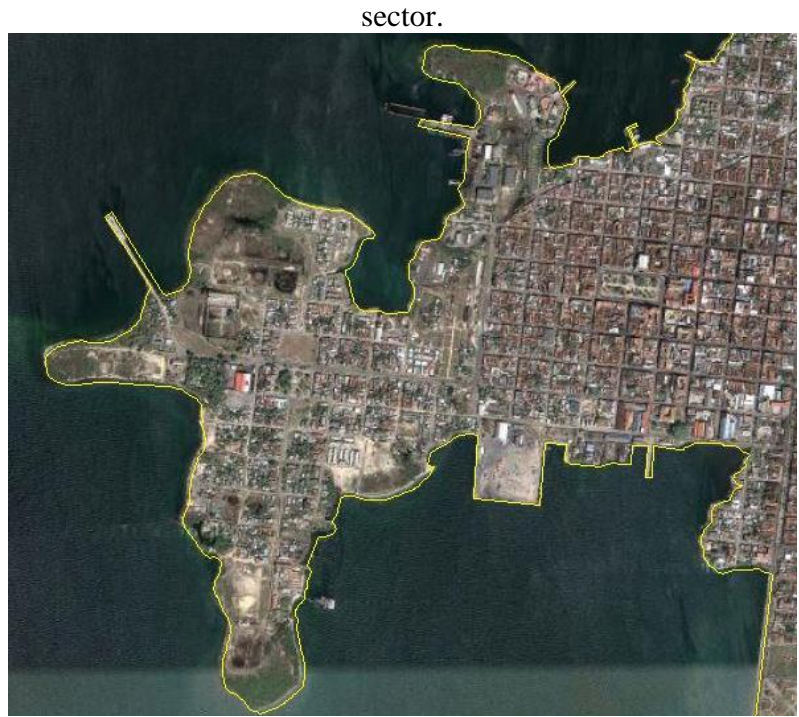

Figure 9. Result of the vector generated over an anthropized coast sector.
After finished all process 27 sectors of coast were obtained by turning to NDWI the SENTINEL 2 images corresponding to the Republic of Cuba, 16 of them corresponding to the drought season and 11 to the rainy one. The figure 10 and 11 show the finals results.

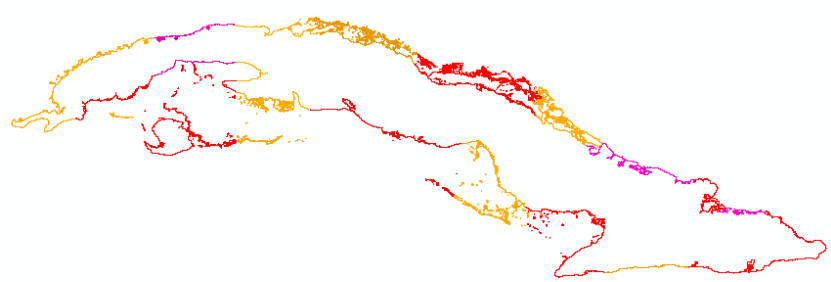

Figure 10. Results of the vectorization of the Cuban archipelago during the dry season

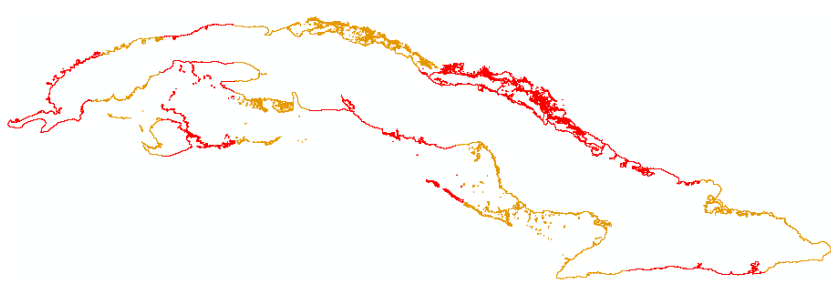

Figure 11. Results of the vectorization of the Cuban archipelago during the rainy season

The planimetric accuracy with which the shoreline vectors were obtained was found to be below the allowable error for the 1:25 000 scale, which is $12.5 \mathrm{~m}$ according to (Comité Estatal de Normalización, 1992).

The estimation of the surface was executed corresponding to two moments of the year 2016, one relative to the dry season and the other to the rainy season. Although not the most appropriate for the determination of areas, the Lambert Conformal Conic projection was used with the transformation parameters of North Cuba as it is the official projection established by the National Office of Hydrography and Geodesy. The estimation was carried out from the semiautomated calculation using a Geographic Information System (GIS). The results are summarized in Tables 1 and 2:

\begin{tabular}{|c|c|c|c|c|}
\hline Concept & $\begin{array}{c}\text { Cuban } \\
\text { archipelago }\end{array}$ & $\begin{array}{c}\text { Cuban } \\
\text { Island }\end{array}$ & $\begin{array}{c}\text { Isle of } \\
\text { Youth }\end{array}$ & $\begin{array}{c}\text { Adjacent } \\
\text { keys }\end{array}$ \\
\hline $\begin{array}{c}\text { area } \\
\mathrm{km}^{2}\end{array}$ & 109884.01 & $\begin{array}{c}104 \\
338.33\end{array}$ & 2419.27 & 3126.41 \\
\hline
\end{tabular}

Table 1. Official data published in the Statistic yearbook of 2016

\begin{tabular}{|l|c|c|c|c|}
\hline $\begin{array}{c}\text { According } \\
\text { to a } \\
\text { season }\end{array}$ & $\begin{array}{c}\text { Cuban } \\
\text { archipelago }\end{array}$ & $\begin{array}{c}\text { Cuban } \\
\text { Island }\end{array}$ & $\begin{array}{c}\text { Isle of } \\
\text { Youth }\end{array}$ & $\begin{array}{c}\text { Adjacent } \\
\text { keys }\end{array}$ \\
\hline $\begin{array}{l}\text { Dry } \\
\text { (area km²) }\end{array}$ & 109460.99 & 104701.09 & 2192.43 & 2567.47 \\
\hline $\begin{array}{l}\text { Rainy } \\
\text { (area km²) }\end{array}$ & 109300.91 & 104643.18 & 2194.99 & 2462.74 \\
\hline
\end{tabular}

Table 2. Estimation according to results of the research work done for 2016

For what it can be concluded that the Cuban archipelago surface once calculated is of $109300,91 \mathrm{~km}^{2}$ that increases $160 \mathrm{~km}^{2}$ more during drought season. 
Deducting the Island of Cuba and the Isle of Youth, and assuming the counting of elements of over $80 \mathrm{~m}^{2}$ once given the space resolution of the used images, the number of emerged elements it was verified that there is a total of 27020 emerged elements in drought season and 22901 in the rainy one, what represents that approximately 4119 are found submerged in rainy periods.

Regarding the estimation of the extension of the coasts, the calculations carried out through this investigation provided the results that are summarized in Tables 3 and 4.

\begin{tabular}{|c|c|c|c|c|}
\hline Concept & $\begin{array}{c}\text { Cuban } \\
\text { Island }\end{array}$ & $\begin{array}{c}\text { North } \\
\text { Coast }\end{array}$ & $\begin{array}{c}\text { South } \\
\text { Coast }\end{array}$ & $\begin{array}{c}\text { Isle of } \\
\text { Youth }\end{array}$ \\
\hline $\begin{array}{c}\text { Coast } \\
(\mathrm{km})\end{array}$ & 5746.00 & 3209.00 & 2537.00 & 327.00 \\
\hline
\end{tabular}

Table 3. Official data published in the Statistic yearbook of 2016

\begin{tabular}{|l|l|l|l|l|}
\hline $\begin{array}{c}\text { Shoreline } \\
\text { according } \\
\text { to a } \\
\text { season }\end{array}$ & $\begin{array}{c}\text { Cuban } \\
\text { Island }\end{array}$ & $\begin{array}{c}\text { North } \\
\text { Coast }\end{array}$ & $\begin{array}{c}\text { South } \\
\text { Coast }\end{array}$ & $\begin{array}{c}\text { Isle of } \\
\text { Youth }\end{array}$ \\
\hline Dry (km) & 8798.91 & 4662.17 & 4136.74 & 438.91 \\
\hline $\begin{array}{l}\text { Rainy } \\
(\mathrm{km})\end{array}$ & 8636.33 & 4603.73 & 4032.60 & 404.82 \\
\hline
\end{tabular}

Table 4. Assessment according to results of the research work done for 2016

For what it can be concluded that the extension of the Cuban shoreline was estimated in a total of $8636,33 \mathrm{~km}$ out of which $162,58 \mathrm{~km}$ enlarge more in the drought season. Of them, the Northern coast extends in $4603,73 \mathrm{~km}$ and the Southern Coast in $4032,60 \mathrm{~km}$. The Isle of Youth shoreline spreads out 404,82 $\mathrm{km}$ enlarging $34 \mathrm{~km}$ in the drought season.

As we mentioned before, the estimation of the surface of Cuba dates from the 19th century. Successively, the amount of $\mathrm{km}^{2}$ of the country has been changing. The explanation of the radical variations mainly as the methods and technologies of the making of maps as well as the geodetic measurements have been improved, the precision of the works in this sense has been increased. Also, as we mention in the abstract, the coastline does not have a well-defined length as results from the fractallike properties of coastlines whereby the area of a surface varies, depending on the measurement resolution.

The Cuban surface estimation in past has been carried out mainly using printed map sheets that involve themselves, a level of generalization given the need to visualize the elements of the terrain on a paper at a certain scale. The first digital maps that were made in Cuba were created from the digitization of the printed maps, therefore, elements such as the coast are still with a high degree of generalization that leads to a certain extent as conservative.

The calculations executed in this work take as a base the information of the territory extracted from the SENTINEL-2 images that offers a spatial resolution of $10 \mathrm{~m}$ and assuming the counting of land elements of over $80 \mathrm{~m}^{2}$, given the space resolution of the used images. The results of the application of this methodology offer a planimetric precision of $11 \mathrm{~m}$, suitable for a scale 1:25000.

\section{CONCLUSIONS}

The shoreline of the Cuban archipelago was updated from remote sensing images of 2016 in the rainy and drought respectively. Advantage was taken from the goodness of the SENTINEL 2 satellite program that offers a temporary space resolution of $10 \mathrm{~m}$, every 5 days and a spectral of 13 bands. The method used is based on the processes of extraction in automated way by transformation of images to NDWI and automatic vectorization. Nevertheless, it is necessary to undertake a process of cartographic edition where images of high resolutions be used to check and to correct possible errors due to the presence of cloudiness in the image. The results were checked using ortophotographies of high resolution and accomplishing with field work measurements with a GNSS radio receiver of $2 \mathrm{~m}$ of precision, both times it was verified that the planimetric accuracy obtained falls below the allowable error for the map to a 1:25 000 scale. From these results, new estimation of the Cuban surface archipelago were carried out verifying that, (1) the calculated surface of the Cuban archipelago is of $109300,91 \mathrm{~km}^{2}$ that increases $160 \mathrm{~km}^{2}$ more in drought season, (2) the number of emerged elements is equal to 27020 in drought season and 22901 during the rainy one, which represents that approximately 4119 are found submerged in rainy periods, (3) the extension of the coasts of the Island of Cuba was estimated in a total of $8636,33 \mathrm{~km}$ that enlarge $162,58 \mathrm{~km}$ more in the drought season, of them the Northern coast extends $4603,73 \mathrm{~km}$ and the Southern coast 4032,60 km.

\section{REFERENCES AND SELECTED BIBLIOGRAPHY}

Álvarez Portal, R., Interián Pérez, S., Ojeda Martínez, D., \& Mantilla Áviles, M. (2009). Metodología de actualización de la carta náutica a escala 1:150 000 mediante imágenes satelitales. . In G. IC (Ed.). La Habana.

Norma Cubana: Mapas Topográficos a escala 1:25 000; 1:50 000 y 1:100 000. Especificaciones de Calidad, 13-10 C.F.R. (1992).

Curra Sánchez, E. D. (2012). El Procesamiento Digital de Imágenes y el análisis estadístico en la investigación de la dinámica de costas. Caso de estudio: playas del oeste en La Habana, Cuba. (Lic.), Universidad de La Habana.

Choung, Y.-J., \& Jo, M.-H. (2017). Comparison between a Machine-Learning-Based Method and a Water-IndexBased Method for Shoreline Mapping Using a HighResolution Satellite Image Acquired in Hwado Island, South Korea. Journal of Sensors, 2017, 13. doi: $10.1155 / 2017 / 8245204$

Choung, Y. J. (2015). Mapping 3D Shorelines Using KOMPSAT-2 Imagery and Airborne Lidar Data. Journal of the Korean Society of Surveying, Geodesy, Photogrammetry and Cartography, 33(1), 23-30.

Emran, A., Rob, M. A., Kabir, M. H., \& Islam, M. N. (2016). Modeling spatio-temporal shoreline and areal dynamics of coastal island using geospatial technique. Modeling Earth Systems and Environment, 2(1), 4.

European Space Agency. (2017). SENTINEL Online. from https://sentinel.esa.int/web/sentinel/home

Hapke, C. J., Himmelstoss, E. A., Kratzmann, M. G., List, J. H., \& Thieler, E. R. ( 2010). National Assessment Of Shoreline Change: Historical Shoreline Changes along the New England and Mid-Atlantic Coasts (pp. 40). U.S.A: U.S. Geological Survey. 
Instituto Cubano de Hidrografía. (1989). Resumen geográfico de la navegación del archipiélago cubano Derrotero de las costas de Cuba (Vol. 1, pp. 20-23).

Kraak, M.-J., \& Ormeling, F. (2010). Map characteristics Cartography: Visualization of Geospatial Data (pp. 152-158). England: Pearson Education Limited.

Maglione, P., Parente, C., \& Vallario, A. (2014). Coastline extraction using high resolution WorldView-2 satellite imagery. European Journal of Remote Sensing, 47(1), 685-699.

Martínez Serrano, A. (2010). Descripción cartográfica de los procesos de erosión en la línea de costa y los cambios en la cobertura vegetal, a partir de fotos aéreas e imágenes de satélite google earth pro en el asentamiento "Playa del Cajío". Ciencias de la Tierra y el Espacio, 11, 34-46.

Moore, L. J. (2000). Shoreline mapping techniques. Journal of coastal research, 111-124.

Olivera Acosta, J. (2015). Determinación de la línea de costa a partir del procesamiento digital de imágenes Landsat.: Instituto de Geografía Tropical.

ONEI. (2016). Anuario Estadístico de Cuba. In Territorio (Ed.). República de Cuba: Oficina Nacional de Estadísticas e Información.

Salitchev, K. A. (1979). Base matemática de los mapas geográficos. In P. y. Educación (Ed.), Cartografía. Plaza de la Revolución. 